\title{
The effects of beta2 adrenergic receptor gene polymorphism in
} lipid profiles

\author{
Wei-Tsung Kao ${ }^{1,2}$, Yung-Chieh Yen $^{3}$ and For-Wey Lung*1,4,5,6
}

Address: ${ }^{1}$ Department of Medicine, Kaohsiung Armed Forces General Hospital, Kaohsiung, Taiwan, ${ }^{2}$ Graduate School of Human Sexuality, ShuTe University, Kaohsiung County, Taiwan, ${ }^{3}$ Department of Psychiatry, E-Da Hospital, and College of Medicine, I-Shou University, Kaohsiung County, Taiwan, ${ }^{4}$ Graduate Institute of Behavior Sciences, Kaohsiung Medical University, Kaohsiung, Taiwan, ${ }^{5}$ Department of Psychiatry, National Defense Medical Center, Taipei, Taiwan and ${ }^{6}$ Calo Psychiatric Center, Pingtung County, Taiwan

Email: Wei-Tsung Kao - 030854@gmail.com; Yung-Chieh Yen - jackycyen@yahoo.com; For-Wey Lung* - forwey@seed.net.tw

* Corresponding author

Published: 21 May 2008

Lipids in Health and Disease 2008, 7:20 doi:10.1186/I476-5IIX-7-20

This article is available from: http://www.lipidworld.com/content/7///20

(C) 2008 Kao et al; licensee BioMed Central Ltd.

This is an Open Access article distributed under the terms of the Creative Commons Attribution License (http://creativecommons.org/licenses/by/2.0), which permits unrestricted use, distribution, and reproduction in any medium, provided the original work is properly cited.

\begin{abstract}
Background: Explore the interaction between apolipoprotein $E$ (Apo E), phospholipase A2 (PLA2) and $\beta 2$ adrenergic receptor ( $\beta 2-\mathrm{AR})$ gene polymorphisms and lipid profiles in an elderly Chinese population.
\end{abstract}

Methods: Five hundred subjects aged 65 to 74 years were randomly selected from a community in southern Taiwan to assess the relationship between Apo E, PLA2 and $\beta 2-A R$ gene polymorphisms and lipid profiles. Two hundred sixty-seven participants agreed to have venous blood drawn for DNA studies.

Results: Two statistically significant differences were noted in TC and LDL-C in the Gln27Glu of the $\beta 2$-AR gene polymorphism $(P=0.007, P=0.022)$. The low-income group had a higher HDL-C level $(p=0.076$ ). The Gln27Glu polymorphism Glu/Glu or $\mathrm{Gln} / \mathrm{Glu}$ subjects had lower TC levels compared to the Gln27Glu polymorphism $G \ln / G \ln$ subjects $(p=0.092)$. Lower TC levels $(p=$ $0.082)$ and lower LDL-C levels $(p=0.045)$ in subjects with the Cys ${ }^{19} \mathrm{Arg}^{16} \mathrm{Glu}^{27}$ haplotype. Lower TC levels $(p=0.06)$ were also noted in subjects with the Cys ${ }^{19} \mathrm{Gly}{ }^{16} \mathrm{Glu}{ }^{27}$ haplotype. On the other hand, higher VLDL-C levels $(p=0.185)$ and higher triglyceride $(T G)$ levels $(p=0.190)$ were noted in subjects with the Cys ${ }^{19} \mathrm{Gly}{ }^{16} \mathrm{Gln}^{27}$ haplotype. The $\varepsilon 2$ allele combined with low income had a positive effect on HDL-C ( $p=0.001 \mathrm{I})$, after adding the income factor in this study.

Conclusion: When the effects of Apo E and PLA2 on lipid profiles were included in this study, $\beta 2$ AR gene polymorphisms reduced significant effect on lipid profiles. Similarly, low income increased effect on HDL-C. This study appeared that the results of gene-gene and gene-environment interaction, it should be considered in further studies for lipid profiles.

\section{Background}

In a previous study, endogenous catecholamines were involved in the regulation of adipose tissue lipolysis, nonesterified fatty acid distribution, lipoprotein metabolism, obesity, glucose homeostasis, diabetes mellitus, blood pressure and metabolic syndrome [1]. Metabolic syndrome was defined as abdominal obesity, hyperglycemia, hypertension, hypertriglyceridemia and low high-density lipoprotein cholesterol (HDL-C). Adrenergic receptors (ARs) can regulate lipid mobilization, energy expenditure 
and glycogen breakdown through these endogenous catecholamines [1]. Catecholamines have been found to act through both $\beta$ - and $\alpha$-adrenergic receptors, which mediate their effects through different receptor pathways. Besides, many studies have demonstrated associations between $\beta 2$ adrenergic receptor ( $\beta 2$-AR) gene polymorphisms and various diseases: obesity, type 2 diabetes (T2DM) [2], metabolic syndrome, metabolic disorders $[3,4]$ and hypertension $[5,6]$. Therefore, the $\beta 2$-AR gene may constitute a potential candidate gene to explain part of the genetic predisposition to human obesity and related traits.

Yang-Feng et al. reported that human $\beta 2$-AR gene polymorphisms were located on the distal portion of the long arm of chromosome 5 (5q32-q34) [7]. Several polymorphisms have been found in the coding region of the $\beta 2-\mathrm{AR}$ gene (Gly16Arg, Gln27Glu and Thr164Ile) and in the promoter region (5'LC-Cys19Arg), each of them leading to amino-acid substitution [8]. In their studies, Dallongeville et al. found that the Gly16Arg and GIn27Glu variants of the $\beta 2$-AR gene contribute to metabolic syndrome susceptibility in men [4] Large et al. found that the Gln27Glu polymorphism of the $\beta 2$-AR gene was markedly associated with obesity with a relatively higher risk for obesity and an odds ratio of approximately 10 [9]. The 5'LC-Cys19Arg protein modulates receptor translation [10], and Gly16Arg and Gln27Glu alterations of cellular trafficking and receptor desensitization [11-13] were found. Furthermore, another study [14] showed a significant association between the three polymorphisms of the 32 -AR gene, 5'LC-Cys19Arg, Gly16Arg and Gln27Glu, and triglyceride (TG) and low-density lipoprotein cholesterol (LDL-C) plasma levels. So we hypothesized that the associations of these three single nucleotide polymorphisms (SNPs): 5'LC-Cys19Arg, Gly16Arg and Gln27Glu, and haplotypes of the $\beta 2$-AR gene with lipid profiles, would be present in our study. In light of these considerations, we conducted a study in an ethnic Chinese elderly population to investigate the role of the three polymorphisms, 5'LC-Cys19Arg, Gly16Arg and Gln27Glu, of the $\beta 2$-AR gene and related haplotypes in lipid profiles in elderly subjects.

The relationship between elevated serum total cholesterol (TC) and LDL-C concentrations, low HDL-C concentrations, and coronary heart disease in middle age [15-18] and early old age has been established [19]. In a past study [20], we established a possible module map among apolipoprotein E (Apo E), phospholipase A2 (PLA2) polymorphism, and lipid profiles in an elderly ethnic Chinese population. The presence of a physiologic balance contributed significantly to homeostasis and compensatory responses regulation of blood HDL-C and LDL-C profiles. In other past studies $[21,22]$, we found the protective effect of the APo\&2 allele against Alzheimer's disease and the higher risk of Alzheimer's disease in subjects with the APo 4 allele. And in another study [23], $\beta$-blockers were found to worsen delayed memory function in people with cognitive impairment, and adrenergic signaling was important for the retrieval of intermediate-term contextual and spatial memories. Furthermore, we thought that ApoE, PLA2 and $\beta 2$-AR might all affect the lipid profiles and have interactions with each other, and associations with the causes of Alzheimer's disease. This study aimed to further explore the interactions between ApoE, PLA2 and $\beta 2$-AR gene polymorphisms and lipid profiles in an elderly ethnic Chinese population.

\section{Materials and methods Participants}

Employing a multilevel stratified sampling strategy, we selected subjects from the official household records of an entire prefecture in southern Taiwan. Three hierarchical household classifications below the county level were sequentially randomly sampled. A total of 500 healthy subjects without major medical diseases and mental illness aged older than 65 years was recruited for this study. There were 267 agreed to have venous blood drawn for DNA extraction for genetic study. In a past study [20], we explored the associations between ApoE, PLA2 and lipid profiles in these subjects. Informed consent was obtained, and the surveys were conducted by trained nurses.

\section{Data Collection and Laboratory Methods}

All personal information was obtained during face-to-face interviews. Blood samples were obtained on the morning following a 12-hour fast. Cholesterol and triglyceride levels were determined in plasma, and lipoproteins by enzymatic methods. LDL-C was calculated using the equation of Friedewald et al. [24], and very-low-density lipoprotein cholesterol (VLDL-C) was derived from total cholesterol (TC) after subtracting LDL-C and HDL-C.

We characterized one SNP in the promoter region (5'LCCys19Arg) and two in the coding region (Gly16Arg and Gln27Glu) of the $\beta 2$-AR gene. The missense mutations 5'LC-Cys19Arg, Gly16Arg and Gln27Glu of the $\beta 2$-AR gene were genotyped using the flurogenic 5 ' nuclease assay application of the ABI PRISM 310 HT Sequence Detection System (ABI, Foster City, USA). Genotyping of the 5'LC-Cys19Arg was performed using primers (0.9 mmol/l each) Forward 5'-CCGCTGAATGAGGCTTCCA-3' and Reverse 5'-CCATGGCGCGCAGTCT-3' and the TaqMan MGB probes Fam TCAGCAGGCGGAC and Vic TCAGCGGGCGGAC. Genotyping of the Gly16Arg was performed using primers $(0.9 \mathrm{mmol} / \mathrm{l}$ each) Forward 5'GGCAGCGCCTTCTTGCT-3' and Reverse 5'-ACCCACACCTCGTCCCTTT-3' and the MGB probes Fam CCCAATGGAAGCCA and Vic CCCAATAGAAGCCATG. 
Table I: Comparison of Participating and Nonparticipating Subjects

\begin{tabular}{|c|c|c|c|}
\hline Variable & Participants $(\mathrm{N}=\mathbf{2 6 7})$ & Nonparticipants $(\mathrm{N}=\mathbf{2 3 3})$ & P* Value \\
\hline Age (yr) Mean (SDs) & 69.18 (2.727) & $69.18(2.832)$ & 0.990 \\
\hline Sex & & & 0.148 \\
\hline Male (\%) & 157 (58.8) & $122(52.4)$ & \\
\hline Female (\%) & $110(41.2)$ & III (47.6) & \\
\hline Education & & & 0.013 \\
\hline Illiterate (\%) & $117(43.8)$ & $128(54.9)$ & \\
\hline Primary school or above (\%) & $150(56.2)$ & $105(45.1)$ & \\
\hline Monthly income (USD) & & & 0.107 \\
\hline$<\$ 860(\%)$ & $193(72.3)$ & $190(81.5)$ & \\
\hline$\$ 860 \sim 2,000(\%)$ & $59(22.1)$ & $33(14.2)$ & \\
\hline$\$ 2,001 \sim 2,860(\%)$ & $12(4.5)$ & $8(3.4)$ & \\
\hline$>\$ 2,860(\%)$ & $3(1.1)$ & $2(0.9)$ & \\
\hline
\end{tabular}

*The $P$ values for the percentages of sex, education, and monthly income refer to $X 2$ tests of differences between participating and nonparticipating subjects. For age, the $P$ value refers to the t-test of differences between participating and nonparticipating subjects.

Genotyping of the Gln27Glu was performed using primers (0.9 mmol/l each) Forward 5'-GCGCCGGACCACGAC-3' and Reverse 5'-CCACCACCCACACCTCGT-3' and the MGB probes Fam TCACGCAGGAAAG and Vic TCACGCAGCAAAG.

Of the $10 \mathrm{ng} / \mathrm{ml}$ stok of DNA, $4 \mathrm{ml}$ were dispensed into 384-well PCR plates using a Biomek FX robot (Beckman Coulter, Fullerton, USA), to which $6 \mathrm{ml}$ of a mix containing the primers, MGB probes and TaqMan Universal PCR Master Mix (ABI, Foster City, CA, USA), were added as per the manufacturers' instructions. These were sealed with optical seals (ABI, Foster City, CA, USA) and incubated for $95^{\circ} \mathrm{C} 10 \mathrm{~min}$, followed by 40 cycles of $95^{\circ} \mathrm{C} 15 \mathrm{~s}$ and $60^{\circ} \mathrm{C} 1 \mathrm{~min}$ before analysis on a $310 \mathrm{HT}$ plate reader (ABI, Foster City, CA, USA).

\section{Statistical Analysis}

The outcomes identified were (1) TC; (2) HDL-C; (3) LDL-C; (4) VLDL-C; and (5) TG levels. Using an analysis of variance, we compared the average levels of plasma lipid among the different genotypes. Data were analyzed using the SPSS version 15.0 for Windows software package (Chicago, IL, U.S.A.). The unpaired t test was used for comparison between groups for continuous variables. Pearson's chi-square test was used for categorical variables. Hardy-Weinberg equilibrium was tested by means of gene counting and chi-square analysis. We used multiple linear regression models to examine the associations of serum lipids and $\beta 2$-AR gene polymorphisms. Analyses examined the lipid profile as continuous variables. Potential confounding variables (sex, age, education and income) were included. In addition, the Jump 5.1 for Windows software package was used to explore the interactive effect among $32-\mathrm{AR}$, PLA2 and Apo E polymorphism, sex, age and income with multivariate regression analysis for HDL-C and LDL-C. We explored the associations between haplotypes of the $\beta 2-A R$ gene and lipid pro- files by using Unphase Version 3.0 [25] and Phase version $2.1[26]$ to code different haplotypes of the $\beta 2-A R$ gene.

\section{Results}

\section{Demographic Characteristics}

Of the 500 subjects recruited in this study, 267 agreed to have venous blood drawn for DNA extraction for genetic study, yielding a response rate of $53.4 \%$. The comparison of the socio-demographic characteristics of our respondents with data from the Ministry of the Interior, Taiwan, revealed that our survey sample did not substantially differ from the national sample [27]. The mean age was 69.2 years old in the case group $(\mathrm{SD}=2.7)$, compared with 69.3 years old in the control group $(S D=2.8)$. The differences in mean age, sex, and monthly income were not statistically significant between the case and control group ( $\mathrm{p}$ $>0.05)$. The case group included more educated persons than the control group ( $\mathrm{p}=0.013)$. The results are shown in Table 1.

\section{B2-AR Polymorphisms Genotypes Frequencies}

The genotype frequencies of these three polymorphisms: 5'LC-Cys19Arg, Gly16Arg and Gln27Glu of $\beta 2$-AR gene were all in Hardy-Weinberg equilibrium in the elderly ethnic Chinese population (5'LC-Cys19Arg Genotypes HWE $\chi^{2}=03372$, Gly16Arg Genotypes HWE $\chi^{2}=0.2135$, Gln27Glu Genotypes HWE $\chi^{2}=0.5541$, all $<\chi^{2} .95=5.99$, $\chi^{2}$ in Hardy-Weinberg equilibrium $\left[\chi^{2} .95<5.99\right.$, $\left.\left.\mathrm{df}=2\right]\right)$. The genotype frequencies of these three polymorphisms are shown in Table 2, but the allele frequencies are not shown. In 5'LC-Cys19Arg polymorphisms, genotype Cys/ Cys appeared most frequently $(\mathrm{n}=256,95.93 \%)$, followed by Cys/Arg $(\mathrm{n}=10,3.7 \%)$, and $\operatorname{Arg} / \operatorname{Arg}(\mathrm{n}=1$, $0.4 \%$ ). In Gly16Arg polymorphisms, genotype Gly/Arg appeared most frequently $(\mathrm{n}=118,44.2 \%)$, followed by $\operatorname{Arg} / \operatorname{Arg}(n=85,31.8 \%)$, and Gly/Gly $(n=46,17.2 \%) ; 18$ cases were undetectable. In Gln27Glu polymorphisms, Genotype Gln/GIn appeared most frequently ( $\mathrm{n}=247$, 
92.5\%), followed by Gln/Glu ( $\mathrm{n}=19,7.1 \%)$, and Glu/ Glu ( $=1,0.4 \%)$.

\section{B2-AR Gene Polymorphisms Association with Plasma Lipid Levels}

Mean values of the overall plasma lipid levels in the elderly Chinese population across these three $\beta 2$-AR gene polymorphism genotypes are shown in Table 2 . The only two statistically significant differences were noted in TC and LDL-C in Gln27Glu of the $\beta 2$-AR gene polymorphism $(\mathrm{P}=0.007, \mathrm{P}=0.022)$. In 5 'LC-Cys19Arg of the $\beta 2$-AR gene polymorphism, Genotype Arg/Arg subjects had higher TC and LDL-C levels, but no statistically significant difference was noted $(\mathrm{P}=0.129, \mathrm{P}=0.138)$, and only one subject had Genotype Arg/Arg. In the $\beta 2$-AR Gly16Arg gene polymorphism, no significant difference was noted.

Using linear regression coefficients between the plasma lipid levels, the Gln27Glu polymorphisms of the $\beta 2$-AR gene, Apo E and PLA2 genotypes, and other possibly related factors (e.g., sex, age, education, income) were summarized, as below (Table 3). Only females had lower TC levels, compared to males, with a statistically significant difference ( $p=0.018$ ). Although Gln27Glu polymorphisms Genotype Glu/Glu or Gln/Glu subjects had lower TC levels compared to Gln27Glu polymorphisms Geno- type Gln/Gln subjects, no statistically significant difference was noted $(p=0.092)$. Furthermore, PLA2 A2 subjects had lower TC levels compared to Non-PLA2 A2 subjects, and TC levels trended downward with increased age, but neither showed a statistically significant difference ( $p=0.057, p=0.053)$. In HDL-C, the positive effects of the $\varepsilon 2$ allele and female sex were statistically significantly $(\mathrm{P}=0.032, \mathrm{p}=0.027)$. Age, PLA2 A2 allele effect and Glu effect on Gln27Glu polymorphisms in the $\beta 2-\mathrm{AR}$ gene were not statistically significant. In LDL-C, the negative effects of the PLA2 A2 allele and age were significant $(p=0.037, p=0.039)$. The $\varepsilon 2$ allele effect, the Glu effect on Gln27Glu polymorphisms in the $\beta 2$-AR gene, and female sex were not statistically significant.

\section{Income Associated with Plasma Lipid Levels}

The 267 elderly subjects were then divided into two groups based on income: those with monthly income less than 860 USD (low income group; 193 subjects) and those with income of 860 USD or more (high income group; 74 subjects). We explored the different lipid profiles between the high income group and low-income group. In spite of the lack of statistically significant difference, the low-income group seemed to have a higher HDL-C level (standardized coefficient $=0.109, \mathrm{t}=1.781$, $\mathrm{p}=0.076$, data not shown).

Table 2: $\beta$ 2-AR Genotype Frequencies and Plasma Lipids Among Genetically Unrelated Elderly Ethnic Chinese Individuals

\begin{tabular}{lcccc}
\hline 5'LC-Cys I 9Arg genotypes & & & \\
\hline Lipid level* & Arg/Arg $(\mathbf{n}=\mathbf{~ I})$ & Arg/Cys $(\mathbf{n}=\mathbf{~ 1 0 )}$ & Cys/Cys $(\mathbf{n}=\mathbf{2 5 6})$ & $\mathbf{P}$ Value $\dagger$ \\
\hline TC & 282.0 & $200.0(23.1)$ & $215.15(40.2)$ & 0.129 \\
HDL-C & 47.0 & $45.3(12.4)$ & $51.13(14.1)$ & 0.422 \\
LDL-C & 204.0 & $129.7(18.8)$ & $137.42(35.9)$ & 0.138 \\
VLDL-C & 31.0 & $25.0(10.5)$ & $26.67(15.4)$ & 0.906 \\
TG & 151.0 & $127.0(53.9)$ & $133.52(77.1)$ & 0.940
\end{tabular}

\section{Gly I6Arg genotypes}

\begin{tabular}{|c|c|c|c|c|}
\hline Lipid level* & $\operatorname{Arg} / \operatorname{Arg}(n=85)$ & Gly/Arg (n = I I8) & Gly/Gly $(n=46)$ & P Value \\
\hline TC & $216.47(40.862)$ & $216.10(4 \mid .5)$ & $209.35(39.2)$ & 0.770 \\
\hline HDL-C & $51.92(14.588)$ & $50.97(14.8)$ & $51.22(12.3)$ & 0.283 \\
\hline LDL-C & $139.54(36.410)$ & I 38.03 (34.9) & $131.70(36.5)$ & 0.679 \\
\hline VLDL-C & $25.01(13.626)$ & $27.28(14.9)$ & $26.43(18.9)$ & 0.512 \\
\hline TG & $25.28(68.208)$ & $136.82(74.7)$ & 132.17 (94.4) & 0.527 \\
\hline
\end{tabular}

\section{GIn27Glu genotypes}

\begin{tabular}{lcccc}
\hline Lipid level* & GIn/GIn $(\mathbf{n}=\mathbf{2 4 7})$ & Gln/Glu $(\mathbf{n}=1 \mathbf{9})$ & Glu/Glu $(\mathbf{n}=\mathbf{I})$ & P Value $\dagger$ \\
TC & $216.42(40.287)$ & $190.63(35.7)$ & 282.0 & 0.007 \\
HDL-C & $51.20(14.276)$ & $47.21(11.1)$ & 27.0 & 0.475 \\
LDL-C & $138.36(35.378)$ & $121.21(33.0)$ & 31.0 & 0.022 \\
VLDL-C & $26.95(15.590)$ & $22.21(8.8)$ & 151.0 & 0.410 \\
TG & $134.90(78.011)$ & $112.11(45.3)$ & 0.443
\end{tabular}

*Lipid level: mean (SDs) (mg/dL)

† The $P$ values for all variables refer to $F$ tests of differences between the $\beta 2-A R$ genotype categories. 


\section{Different Haplotypes of the $\beta 2-A R$ gene Associated with Plasma Lipid Levels}

Based on the different genotypes of these three polymorphisms, 5'LC-Cys19Arg, Gly16Arg and Gln27Glu of the $\beta 2$-AR gene, we had different haplotypes of the $\beta 2-A R$ gene. By using Unphase Version 3.0 analysis, we coded the different haplotypes of the $\beta 2$-AR gene, and then explored the associations between the different haplotypes and lipid profiles of these elderly subjects. We found that only the $\mathrm{Cys}^{19} \mathrm{Arg}^{16} \mathrm{Glu}^{27}$ haplotype and the Cys ${ }^{19} \mathrm{Gly}^{16} \mathrm{Glu}^{27}$ haplotype in subjects had some association with lipid profiles. We found lower TC levels ( $\mathrm{p}=$ $0.082)$ and lower LDL-C levels $(p=0.045)$ in subjects with the $\mathrm{Cys}^{19} \mathrm{Arg}^{16} \mathrm{Glu}^{27}$ haplotype, and also lower TC levels $(p=0.06)$ in subjects with the Cys ${ }^{19} \mathrm{Gly}^{16} \mathrm{Glu}^{27}$ haplotype (Table 4). Only two subjects had the Cys ${ }^{19} \mathrm{Arg}^{16} \mathrm{Glu}^{27}$ haplotype and six subjects, the Cys ${ }^{19} \mathrm{Gly}$ ${ }^{16} \mathrm{Glu}^{27}$ haplotype. We also found higher VLDL-C (P = $0.185)$ and higher TG levels $(P=0.190)$ in subjects with the Cys ${ }^{19}$ Gly ${ }^{16} \mathrm{Gln}^{27}$ haplotype. However, the above results did not reach statistical significance.

Using Phase Version 2.1 analysis to define the haplotypes of all subjects, we found that each subject in this study had two sequences of haplotypes of the $\beta 2$-AR gene. We then divided these elderly subjects into two groups, according to whether they possessed the Cys ${ }^{19} \mathrm{Gly}{ }^{16} \mathrm{Gln}^{27}$ haplotype or not. We could not find any statistically significant difference in lipid profiles between these two groups of elderly, using logistic regression analysis.

\section{Discussion}

In our study, the $\varepsilon 2$ allele and female sex had statistically significant $(\mathrm{p}=0.032, \mathrm{p}=0.027)$ positive effects on HDL$\mathrm{C}$. The low income group also seemed to have higher HDL-C levels $(P=0.076)$. In LDL-C, the PLA2 A2 allele and age had significantly ( $\mathrm{p}=0.037, \mathrm{p}=0.039)$ negative effects. So, we explored the interactive effects among PLA2 and the Apo E polymorphism, sex and income on HDL-C, using multivariate regression analysis with the Jump 5.1 for Windows software package. We found that the $\varepsilon 2$ allele combined with low income had a positive effect on HDL-C ( $\mathrm{p}=0.0011)$. We also found that the A2 allele combined with the $\varepsilon 2$ allele had a positive effect on LDL$\mathrm{C}(\mathrm{p}=0.0002)$.

In another study [14], Petrone et al. found that 5'LC-Cys ${ }^{19}$ homozygous showed higher TG and LDL-C levels compared to $5^{\prime} \mathrm{LC}-\operatorname{Arg}^{19}$ homozygous. A similar increase in TG and LDL-C levels was observed for the Gly16Arg polymorphism and the Gln27Glu polymorphism. And, they found that the $\mathrm{Cys}^{19} \mathrm{Arg}^{16} \mathrm{Gln}^{27}$ haplotype determined a significant increase in TG and LDL-C levels compared to the $\operatorname{Arg}^{19} \mathrm{Gly}^{16} \mathrm{Glu}^{27}$ haplotype. After performing the final parsimonious model of multiple linear regression coefficients between the plasma lipid levels, the Gln27Glu polymorphism of the $\beta 2-\mathrm{AR}$ gene, Apo $\mathrm{E}$ and PLA2 genotypes, and other possibly related factors, the Gln27Glu polymorphism Glu/Glu or Gln/Glu subjects had lower TC levels compared to the Gln27Glu polymorphism Gln/Gln subjects, but no statistically significant difference was noted ( $p=0.092$ ) (Table 3$)$. And in different haplotypes of the $\beta 2$-AR gene associated with plasma lipid levels, we found significantly lower TC levels ( $\mathrm{p}=$ $0.082)$ and lower LDL-C levels $(\mathrm{p}=0.045)$ in subjects with the Cys ${ }^{19} \mathrm{Arg}^{16} \mathrm{Glu}^{27}$ haplotype, and significant lower TC levels $(\mathrm{p}=0.06)$ in subjects with the Cys ${ }^{19} \mathrm{Gly}{ }^{16} \mathrm{Glu}^{27}$ haplotype (Table 4). But there were too few subjects with these two haplotypes. We also found higher VLDL-C levels $(p=0.185)$ and higher TG levels $(p=0.190)$ in subjects with the Cys ${ }^{19} \mathrm{Gly}{ }^{16} \mathrm{Gln}^{27}$ haplotype. Altogether, none of our results showed a statistically significant difference.

However, we believe that the difference in results between our study and the study by Petrone et al. ${ }^{15}$ regarding the $\beta 2$-AR gene may be due to the following reasons. Firstly, their subjects were overweight/obese subjects (body mass index $[\mathrm{BMI}]>25 \mathrm{~kg} / \mathrm{m}^{2}$ ), who were consecutively recruited from the metabolic day hospital of the Department of Clinical Sciences of their university. Our subjects

Table 3: The Parsimonious Model for TC, HDL-C and LDL-C

\begin{tabular}{|c|c|c|c|c|c|c|}
\hline \multirow[b]{2}{*}{ Variables } & \multicolumn{2}{|c|}{$\mathrm{TC}$} & \multicolumn{2}{|c|}{ HDL-C } & \multicolumn{2}{|c|}{ LDL-C } \\
\hline & Coef (S.E.) & $\mathrm{P}$ & Coef (S.E.) & $\mathrm{P}$ & Coef (S.E.) & $P$ \\
\hline$\varepsilon 2$ allele effect & $9.9(13.9)$ & 0.474 & $11.0(5.1)$ & 0.032 & $2.2(12.2)$ & 0.860 \\
\hline A2 allele effect & $-9.6(5.0)$ & 0.057 & $1.3(1.8)$ & 0.486 & $-9.3(4.4)$ & 0.037 \\
\hline Glu effect & $-16.1(9.5)$ & 0.092 & $-2.9(3.5)$ & 0.401 & $-8.2(8.4)$ & 0.333 \\
\hline Sex & $12.1(5.1)$ & 0.018 & $4.2(1.9)$ & 0.027 & $6.3(4.5)$ & 0.164 \\
\hline Age & $-1.8(0.9)$ & 0.053 & $0.3(0.3)$ & 0.442 & $-1.7(0.8)$ & 0.039 \\
\hline
\end{tabular}

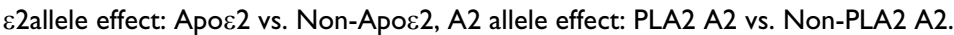

Glu effect: Genotype Glu/Glu, Gln/Glu vs. Genotype Gln/Gln in Gln27Glu Genotypes of $\beta 2-A R$ gene. Sex: female vs. male

TC: Total cholesterol; HDL-C: high-density lipoprotein cholesterol; LDL-C: Low-density lipoprotein cholesterol

Coef: Estimate coefficient; S.E.: Standard error; P: P value 
were selected from southern Taiwan, and were older than 65 years when they were recruited for this study. The difference in subjects between their study and our study may have led to the different results. And we had not let our subjects to check BMI in our study. So we can not discuss the impact of BMI on lipid profiles. On the other hand, we had not use case-control study to evaluate the different lipid profiles between obesity subjects and control cases. Secondly, our study had fewer subjects than theirs, and there were fewer frequencies of some polymorphisms of the $\beta 2$-AR gene. The fewer subjects may have led to subjects with fewer of some polymorphisms of the $\beta 2$-AR gene, thus leading to different results. In our study, the lipid profiles of the individual homozygous for the 5'LCArg19 allele and the lipid profile of the individual homozygous for the Glu27 allele are identical maybe due to this is the same individual. Thirdly, in their study, they only defined the frequency of each haplotype, and not the haplotypes of every subject. In our study, we used Phase Version 2.1 with Baysin analysis to define the haplotypes of all subjects to reduce the false positive rate [23].

On the other hand, we were also concerned that epistasis may present between multiple genes in lipid profiles. The low income group seemed to have a higher HDL-C level $(\mathrm{p}=0.076)$ in our study, but in spite of this result not reaching statistically significant difference, we still wanted to add the income factor. After adding the income factor in the study, we found that the $\varepsilon 2$ allele combined with low income had a positive effect on HDL-C ( $p=0.0011)$. In our past study [20], we also found the opposite effects of the $\varepsilon 2$ allele and the PLA2 A2 allele on HDL-C and LDL$\mathrm{C}$. The presence of the $\varepsilon 2$ allele with the PLA2 A2 allele appeared to significantly decrease HDL-C, and the PLA2 A2 allele with the presence of the $\varepsilon 2$ allele increased LDLC.

\section{Conclusion}

We concluded that not only do biological factors like Apo E, PLA2 and $\beta 2$-AR affect lipid profiles, but social factors like income may also affect lipid profiles. We need to explore more of the effects that can affect lipid profiles to establish a clearer model to explain the interaction between genetic factors, social factors, and lipid profiles in the future. Using the model, if we can find high risk groups for hyperlipidemia and related disorders like metabolic syndrome, diabetes, cardiovascular disease, and obesity, and adopt adequate solutions, the prevalence of these disorders may be reduced. On the other hand, we may also have a clearer understanding of the causes of Alzheimer's disease using the model.

\section{Authors' contributions}

FW had full access to all the design for this study, take responsibility for the integrity of the data and accuracy of
Table 4: Plasma Lipids by Different $\beta 2$-AR Gene Haplotypes Among Genetically Unrelated Elderly Chinese Individuals

\begin{tabular}{|c|c|c|c|}
\hline Lipid level* & Non-TGC & TGC & P Value ${ }^{\dagger}$ \\
\hline $\mathrm{TC}$ & $214.69(41.060)$ & $214.66(40.298)$ & 0.994 \\
\hline HDL-C & $51.11(14.285)$ & $50.74(14.044)$ & $0.84 I$ \\
\hline LDL-C & $138.64(36.229)$ & $136.49(35.255)$ & 0.638 \\
\hline VLDL-C & $24.95(13.279)$ & $27.54(16.246)$ & 0.185 \\
\hline TG & $125.03(66.570)$ & I $37.88(81.280)$ & 0.190 \\
\hline Lipid level* & Non-TGG & TGG & P Value ${ }^{\dagger}$ \\
\hline TC & 215.38 (39.954) & $184.00(55.328)$ & 0.060 \\
\hline HDL-C & $50.98(14.182)$ & $46.33(10.013)$ & 0.426 \\
\hline LDL-C & $137.68(35.176)$ & I I $9.50(50.087)$ & 0.216 \\
\hline VLDL-C & 26.81 (I5.377) & $18.17(5.456)$ & 0.171 \\
\hline TG & I34.27 (76.960) & 90.17 (26.947) & 0.163 \\
\hline Lipid level* & Non-TAC & TAC & P Value ${ }^{\dagger}$ \\
\hline TC & $209.82(39.488)$ & 215.66 (40.7I5 & 0.379 \\
\hline HDL-C & 51.31 (12.387) & $50.78(14.455)$ & 0.819 \\
\hline LDL-C & I $32.07(36.84 \mid)$ & $138.33(35.276)$ & 0.283 \\
\hline VLDL-C & $26.44(19.113)$ & $26.65(14.416)$ & 0.936 \\
\hline TG & 132.22 (95.497) & $133.49(72.206)$ & 0.919 \\
\hline Lipid level* & Non-TAG & TAG & P Value ${ }^{\dagger}$ \\
\hline TC & 215.05 (40.399) & $165.00(18.385)$ & 0.082 \\
\hline HDL-C & $50.81(14.138)$ & $59.50(2.121)$ & 0.386 \\
\hline LDL-C & 137.65 (35.377) & $87.00(26.870)$ & 0.045 \\
\hline VLDL-C & $26.67(15.311)$ & $18.50(6.364)$ & 0.452 \\
\hline TG & I 33.57 (76.639) & $94.50(36.648)$ & 0.473 \\
\hline Lipid level* & Non-CGG & CGG & P Value ${ }^{\dagger}$ \\
\hline TC & $214.98(40.812)$ & $207.45(40.8 \mid 2)$ & 0.547 \\
\hline HDL-C & $51.11(14.171)$ & $45.45(33.040)$ & 0.194 \\
\hline LDL-C & $137.30(35.870)$ & $136.45(28.623)$ & 0.939 \\
\hline VLDL-C & $26.66(15.470)$ & $25.55(10.152)$ & 0.814 \\
\hline TG & I33.45 (77.4I6) & $129.18(51.610)$ & 0.856 \\
\hline
\end{tabular}

* Lipid level: mean (SDs) (mg/dL); † The $P$ values for all variables refer to $T$ tests of differences between the two groups.

TGC: $\mathrm{Cys}^{19} \mathrm{Gly}^{16} \mathrm{Gln}^{27}$; TGG: Cys ${ }^{19} \mathrm{Gly}{ }^{16} \mathrm{Glu}^{2}$; TAC: $\mathrm{Cys}{ }^{19} \mathrm{Arg}{ }^{16} \mathrm{Gln}$; TAG: $\mathrm{Cys}^{19} \mathrm{Arg}^{16} \mathrm{Glu}^{27}$; CGG: $\mathrm{Arg}^{19} \mathrm{Gly}^{16} \mathrm{Glu}^{27}$

the data analysis, and drafted the final manuscript, WT have carried out the molecular genetic studies, performed the statistical analysis, and drafted the manuscript, YC have conceived of the study, participated in its design and performed the statistical analysis. All authors read and approved the final manuscript.

\section{Acknowledgements}

This study was supported by a grant (numbers 9625) from the Medical Affairs Bureau, Ministry of National Defense, Taiwan. The authors would like to acknowledge all researchers to execute this study. 


\section{References}

I. Insel PA: Seminars in medicine of the Beth Israel Hospital, Boston. Adrenergic receptors evolving concepts and clinical implications (Review). N Engl J Med 1996, 334:580-585.

2. Yamada K, Ishiyama-Shigemoto S, Ichikawa F, Yuan X, Koyanagi A, Koyama W, Nonaka K: Polymorphism in the 5'-leader cistron of the $B_{2}$-adrenergic receptor gene associated with obesity and type 2 diabetes. J Clin Endocrinol Metab 1999, 84: I754-I757.

3. Ishiyama-Shigemoto S, Yamada K, Yuan X, Ichikawa F, Nonaka K: Association of polymorphisms in the beta2-adrenergic receptor gene with obesity, hypertriglyceridaemia, and diabetes mellitus. Diabetologia 1999, 42:98-I0I.

4. Dallongeville J, Helbecque N, Cottel D, Amouyel P, Meirhaeghe A: The Gly I 6-Arg 16 and GIn27-Glu27 polymorphisms of beta2adrenergic receptor are associated with metabolic syndrome in men. J Clin Endocrinol Metab 2003, 88:4862-4866.

5. Bray MS, Boerwinkle E: The role of beta(2)-adrenergic receptor variation in human hypertension (Review). Curr Hypertens Rep 2000, 2:39-43.

6. Pereira AC, Floriano MS, Mota GF, Cunha RS, Herkenhoff FL, Mill JG, Krieger JE: Beta2 adrenoceptor functional gene variants, obesity, and blood pressure level interactions in the general population. Hypertension 2003, 42:685-692.

7. Yang-Feng TL, Xue FY, Zhong WW, Cotecchia S, Frielle T, Caron MG, Lefkowitz RJ, Francke U: Chromosomal organization of adrenergic receptor genes. Proc Natl Acad Sci USA 1990, 87:1516-1520.

8. Liggett SB: Pharmaconenetics of betal and beta2 adrenergic receptors. Pharmacology 2000, 6 I:167-173.

9. Large V, Hellstrom L, Reynisdottir S, Lonnqvist F, Eriksson P, Lannfelt L, Arner P: Human beta-2 adrenoceptor gene polymorphisms are highly frequent in obesity and associate with altered adipocyte beta-2 adrenoceptor function. I Clin Invest 1997, 100:3005-3013.

10. McGraw DW, Forbes SL, Kramer LA, Liggett SB: Polymorphisms of the 50 leader cistron of the human beta2-adrenergic receptor regulate receptor expression. J Clin Invest 1998, 102:1927-1932.

II. Green SA, Liggett SB: A proline-rich region of the third intracellular loop imparts phenotypic beta I-versus beta 2-adrenergic receptor coupling and sequestration. J Biol Chem 1994, 269:26215-26209.

12. Green SA, Turki J, Bejarano P, Hall IP, Liggett SB: Influence of beta2-adrenergic receptor genotypes on signal trasduction in human airway smooth muscle cells. Am J Respir Cell Mol Biol 1995, 13:25-33.

13. Moore PE, Laporte JD, Abraham JH, Schwartzman IN, Yandava CN, Silverman ES, Drazen JM, Wand MP, Panettieri RA Jr, Shore SA: Polymorphism of the beta(2)-adrenergic receptor gene and desensitization in human airway smooth muscle. Am J Respir Crit Care Med 2000, 162:2117-2124.

14. Petrone A, Zavarella S, lacobellis G, Zampetti S, Vania A, Pietro S, Galgani A, Leonetti F, Di Mario U, Buzzetti R: Association of $\beta 2$ adrenergic receptor polymorphisms and related haplotypes with triglyceride and LDL-cholesterol levels. Eur J Hum Genet 2006, I 4:94-100.

15. Anderson KM, Castelli WP, Levy D: Cholesterol and mortality: $\mathbf{3 0}$ years of follow-up from the Framingham study. JAMA 1987, 257:2176-2180.

16. Gordon DJ, Probstfield JL, Garrison RJ, Neaton JD, Castelli WP, Knoke JD, Jacobs DR Jr, Bangdiwala S, Tyroler HA: High-density lipoprotein cholesterol and cardiovascular disease. Four prospective American studies. Circulation 1989, 79:8-I5.

17. Jacobs DR, Mebane IL, Bangiwala SI, Criqui MH, Tyroler HA: High density lipoprotein cholesterol as a predictor of cardiovascular disease mortality in men and women: the follow-up study of the Lipid Research Clinic Prevalence Study. Am J Epidemiol 1990, I $31: 32-47$.

18. Verschuren WMM, Kromhout D: Total cholesterol concentration and mortality at relatively young age: do men and women differ? BM] 1995, 3 I I:779-783.

19. Barrett-Connor E, Suarez L, Khaw KT, Criqui MH, Wingard DL: Ischaemic heart disease risk factors after age 50. J Chronic Dis 1984, 37:903-908.

20. Lung FW, Kao WT, Shu BC, Yen YC, Tzeng DS: A module map showing interaction between apolipoprotein $E$ and phos- pholipase A2 polymorphism in lipid profiles. Hum Hered 2006, 62:135-144.

21. Lung FW, Yen YC, Chou LJ, Hong CJ, Wu CK: The allele interaction between apolipoprotein e2 and e4 in Taiwanese Alzheimer's disease patients. Acta Psychiatr Scand 2005, I I I:38-43.

22. Yen YC, Liu CK, Lung FW, Chong MY: Apolipoprotein E polymorphism and Alzheimer's disease. Kaohsiung J Med Sci 200I, I 7:190-197.

23. Gliebus G, Lippa CF: The influence of beta-blockers on delayed memory function in people with cognitive impairment. Am J Alzheimers Dis Other Demen 2007, 22:57-6I.

24. Friedewald WT, Levy RI, Fredrickson DS: Estimation of the concentration of low-density lipoprotein cholesterol in plasma, without use of the preparative ultracentrifuge. Clin Chem 1972, I 8:499-502.

25. Dudbridge F: Pedigree disequilibrium tests for multilocus haplotypes. Genet Epidemiol 2003, 25: II5-121.

26. Stephens M, Smith NJ, Donnelly P: A New Statistical Method for Haplotype Reconstruction from Population Data. Am J Hum Genet 200I, 68:978-989.

27. Ministry of the Interior: Ministry of the Interior: A bridged Life Table in Taiwan 200 I Taipei, Taiwan: Ministry of the Interior; 2002.
Publish with Bio Med Central and every scientist can read your work free of charge

"BioMed Central will be the most significant development for disseminating the results of biomedical research in our lifetime. "

Sir Paul Nurse, Cancer Research UK

Your research papers will be:

- available free of charge to the entire biomedical community

- peer reviewed and published immediately upon acceptance

- cited in PubMed and archived on PubMed Central

- yours - you keep the copyright

Submit your manuscript here:

http://www.biomedcentral.com/info/publishing_adv.asp
BioMedcentral 